\title{
The Philosophical Foundations of Islamic Political Economy
}

\author{
Mohammad A. Muqtedar Khan
}

Then we put thee on the right way, So follow thou that; And follow not the desires of those who know not. (Qur'an 45:18)

\section{Introduction}

Westem perceptions of Islam have always been colored by their fear of Islamic expansion and the historical rationality of the Crusades. The current preoccupation with the "clash of civilizations" debate and the extraordinary focus on "Islamic fundamentalism" have greatly politicized the discourse on Islam while preventing a fuller understanding of Islam.' The tendency among Muslim scholars to allow the West to set the agenda of what should be studied in and about Islam has led to the delay of ijtihad in more important areas, such as Islamic political economy. In the age of modemization, thinkers in the West have rejected Islam as backward looking and as an impediment to economic development. ${ }^{2} \mathrm{~A}$ fair interpretation of Islam, however, includes a complete understanding of the need for development and social welfare. The political economy of Islam, as this paper will present, is a completely humanistic and internally consistent development and welfare-oriented paradigm.

In the twentieth century, Islam has survived colonial domination, communist repression, and the rapid spread of liberalism. Today it has a rapidly increasing membership of over one billion and is experiencing a resurgence from Malaysia to Sudan and Algeria and from Iran to the newly independent republics of Central Asia. More and more nations with predominantly Muslim populations are undergoing a burgeoning sense of Islamic consciousness. To some, this is a cohesive global phenomenon with potentially indelible consequences. ${ }^{3}$ They see it as a radical movement that is antithetical to Western liberal values and a challenge to their religious zeal to universalize these values. Regardless of the political constructions of Islam's revival, what is of the essence is that more and more

Mohammed A. Muqtedar Khan is a doctoral fellow in intermational relations, Department of Government, Georgetown University, Washington, DC. An earlier version of this paper was presented at the Mid-West Political Science Association's 52nd Annual Conference at Chicago, 14-16 April 1994. I would like to thank Mohiaddin Mesbahi, Basheer Nafi, Reshma Khan, and the anonymous reviewers of AJISS for their useful suggestions. 
Muslims are turning toward their Islamic heritage for moral and social direction, for cultural and political identity, while their societies are struggling actively to make Islamic principles primary in determining the political and economic nature of their nations.

It is interesting to note the contrasting trends in global society. While one segment is making relentless progress toward a supposedly liberal economic society based on the absolute primacy of the individual self, another segment is battling against autocracy and cultural imperialism in order to resurrect a society based on the primacy of the universal absolute (one God) and the negation of the self. Unlike the liberal perspective, in which human nature is assumed to be manifested by selfish and rational individuals driven by a remorseless desire to maximize their economic benefit, ${ }^{4}$ the Qur'an defines the individual as a pilgrim traversing time, whose every action is subservient to the will of the one and universal God, and whose sole purpose is to worship Him:

$\mathrm{He}$ it is Who created you from clay, and then decreed a stated term.

Ye shall surely travel from stage to stage. (84:19)

But ye shall not will except as Allah wills, - The Cherisher of the worlds. (81:29)

This paper addresses the issue of Islamic political economy. It attempts to understand those philosophical foundations, principles, and instruments of Islam that are the defining characteristics of Islamic political economy.

There is an extensive literature on both the political theories and economic aspects of Islam. However, there is very little work that deals explicitly with Islamic political economy. As defined by Crane and Amawi, political economy is :

focus on phenomena that lie at the cross roads of the traditional fields of political science and economics. It seeks to explain how political power shapes economic outcomes and how economic forces constrain political action. ${ }^{5}$

This definition, however, assumes that politics and economics are distinct phenomena that can be studied separately and that political economy lies somewhere in the middle. My own understanding is that as economics and politics are inseparable aspects of social existence, it would be misleading to study them separately. Thus, the study of political economy becomes a more effective way of studying societies. Hasanuz Zaman articulates the economic functions of an Islamic state. ${ }^{6}$ His work is an example of the rare studies of Islamic political economy. 


\section{A Brief Conceptual History of Islamic Political Economy}

The period from the tenth to the twentieth century was, sadly, an era of reverse renaissance within the Muslim world. Very little ijtihad was done and, consequently, the conceptual development of Islamic economics failed to keep pace with evolving modern markets and the economic consequences of developing technology. It reached a sort of impasse from which it has just begun to awaken. The earliest and most famous Islamic economist, Ibn Khaldūn (1332-1406), made significant advances in issues of comparative advantage and international trade. His work is very similar to that of Adam Smith, who first advocated liberal economics in the seventeenth century.

In his al Muqaddimah, Ibn Khaldūn describes the individual as an economic animal possessing the attribute of rational behavior and, to a degree, also propounds the theory that economic efficiency and survival are major goals. He discusses the domestic and international division of labor and relationships between price, demand, and supply. His merit lies more in his rather precocious development of liberal concepts than in his contribution to Islamic economic theory. Unfortunately, Ibn Khaldūn's work was not taken up and developed by other Muslim scholars for nearly five centuries - a tragedy that has contributed significantly to the stunted development of Islamic political economic thought.

A few authors from Pakistan were the first to revive interest in Islamic economics. Syed Abul A'ala Mawdudi and Anwar Iqbal Qureshi are among the most notable. However, their work was more in the nature of advocacy than scholarship. Serious scholarship began in the late 1970s with Baqer As-Sadr, Khurshid Ahmad, Monzer Kahf, Nawab Haider Naqvi, M. Umer Chapra, M. A. Choudhary, M. Abdul Mannan, and Ozay Mehmet.' Some scholars are attempting to understand Islamic economics within the conceptual framework of conventional economics, while others work within the domain of Islamic epistemology to develop concepts and instruments that can explain economic activity from an Islamic perspective. The former effort is best represented by Naqvi, who draws a parallel between Islamic economic principles and the theory of perfect competition. He develops his model from four ethical axioms: unity, equilibrium, free will, and responsibility. ${ }^{8}$ It is an ideal system wherein Islamic ethics serve as the point of departure for conceptualizing a general equilibrium model. Ahmad, Chapra, and Mannan are good examples of the latter category. The most prominent Shi'i contributor to the development of contemporary Islamic economic thought, who also fits the latter mold, is the illustrious Iraqi scholar and jurist Baqer As-Sadr.

Baqer As-Sader is considered to be a prominent Islamic modernist and one of the main architects of the Islamic renaissance in Najaf between 1940 and $1980 .{ }^{9} \mathrm{He}$ made two important contributions to Islamic economics. The first is the celebrated Iqtișädunā (Our Economic System), which 
critiques Marxism and capitalism while elaborating upon the Islamic principles of economics. The unique quality of this work is that it draws on Islamic fighi thought more than any other source to articulate economic principles. He also wrote al Bank al lã Ribäwĩ fi al Islām (The InterestFree Bank in Islam). In this work, he elaborated the mechanics of interestfree banking.

Ahmad has an interesting perspective on Islamic economics, in that he looks at it within the context of development. ${ }^{10}$ While this makes his approach very instrumental and open to retrospective biases, nevertheless it provides an interesting texture to the literature. This Pakistani scholar and practitioner of repute defines, or rather redefines, the term development from the standpoint of Islam. Development in Islam, he writes, is more than economic output and economic activity; it is a value-oriented activity that includes moral, material, and spiritual components. He places development squarely within the broader concept of human development. Islam, he proclaims, is effort, struggle, movement, and reconstruction-all elements of social change. Thus, Islam equals social change equals all round human development. He identifies four cardinal principles of Islamic development: tawhìd (oneness), rubübiyah (divine arrangement toward perfecting nourishment and sustenance), khiläfah (vicegerency), and tazkiyah (purification and growth). Ahmad's approach, like that of Mannan, is socioeconomic in character.

Muhammed Nejatullah Siddiqui is more famous for the extraordinary survey he published on all aspects of Islamic economics and for his attempt to demonstrate how a social security system can be developed in Islamic societies using the instrument of zakat." This survey, while exhaustive, shows no new approaches to Islamic political economy. This could be for two reasons. Contemporary Islamic thinkers are not really working in Muslim-friendly environments. Most governments in Muslim states are either hostile to or wary of Islam and Islamic thinkers. Thus, invariably Islamic thinkers are compelled to drop political aspects and concentrate on economic aspects. Second, the usefulness of the political economy approach, though as old as Adam Smith and Karl Marx, has been rediscovered in contemporary social science only recently. I hope this paper will help redress this lacuna.

Chapra places the conception of Islamic economics within the broader Islamic worldview. His perspective is holistic, and his analysis is more strategic. ${ }^{12}$ The Islamic worldview, according to him, is based on three fundamental principles: tawhïd, khiläfah, and 'adälah (justice). ${ }^{13}$

Mannan, in his Islamic Ummah: Economic Order and Conceptual Framework, explains how the Islamic paradigm is based on a matrix of the Qur'anic concepts of tawhid (the unity of God and humanity's total submission to Him), äkhirah (life after death), amänah (trust), 'adl (justice), ihsān (kindness), iqtișād (moderation), it tidāl (harmony), tazkiyah (economic growth with more spiritual values), istișlāh (public interest), halāl (that which is beneficial), and haräm (that which is harmful). ${ }^{14}$ There are 
two remarkable aspects in Mannan's work. He conceptualizes the Islamic model as a socioeconomic and not just an economic paradigm. This is a positive approach. Given the metatheoretical nature of Islam and the allpervasive quality of the Qur'anic injunctions, it is not possible to separate social order from economics. In his discussion of the ideological imperative in economics, he states how Islam does not accept the position that economics is neutral toward value.

S. M. Hasanuz Zaman's Economic Functions of an Islamic State is a historical account of the early experiences in operationalizing Islamic political economy. His work is divided into three sections. The first deals with the basic elements of Islamic economics: 'adl, ihsān, zakat, infāq (spending), and ghanimah (booty). His second section focuses primarily on the bayt al mäl (the exchequer), and the third on economic indicators. His work, however, is a historical account up to the period of the Umayyads, and I am a bit reticent about equating, as he does, what is with what ought to be from an Islamic perspective. Thus, while I appreciate Zaman's approach as a truly political economic perspective, I would still classify his work as historical. ${ }^{15}$

Having noted that research and the development of knowledge among Muslims virtually ceased between the time of Ibn Khaldūn and now, it may be said that this great stagnation is perhaps one of the primary causes for the decline of Islamic power. The return to research within an Islamic paradigm is one of the many positive facets of the modern Islamic resurgence.

\section{Socioeconomic Foundations}

The goals of the Islamic paradigm (maqāsid al sharī'ah) are based on the concepts of human well-being (faläh) and the good life (al hayät al tayyabah). ${ }^{16}$ Faith (ïmãn) is at the core of maqässid al sharīah, because it lays the foundation for a society that will ensure universal well-being. According to Mannan, the primary motive is "aggregate welfare." Qur'an, in 6:136, says that God has provided resources in abundance to humanity and they are sufficient-provided that they be distributed with efficiency and equity. ${ }^{18}$ Mannan also points out that the quality, content, composition, and actual distribution of GNP is more important than mere volume. ${ }^{19}$ In addition, he cites nine criteria for the development of an integrative economic model, among which he lists the concept of human equality, distributive justice, the balanced and benevolent use of natural resources, and the principle of coexistence. ${ }^{20}$

No vision of social existence can make sense unless it spells out its conception of human nature, for assumptions and hypotheses about this element form the basic philosophical foundations of any value system. All worldviews are theorized according to these assumptions regarding human nature and humanity's raison d'être. Perspectives would make less sense if they failed to relate to the nature and realities of human existence. By means of their philosophical underpinning, worldviews attempt to address 
the ontological issues of human existence in order to realize their vision of what the world ought to be. Islam explains human nature as that of an intelligent being capable of exercising choice. Furthermore, each human being was created as the khalifah of God on Earth to conquer and rule over it (Qur'an 45:12-13); has an inner self (the soul), which has an intrinsic ability to recognize the signs of God; and experiences an anguish that is expressed in the form of a search for its maker. ${ }^{21}$ Each person is supposed to be inherently good and just; capable of fulfilling his/her social obligations; able to know, learn, and apply one's knowledge to accomplish one's mission in life-to live a life of 'ibädah (worship) and realize the maqãșid. ${ }^{22}$ Humanity, created in the best of molds (Qur'an 95:4), granted the ability to think and reason (Qur'an 90:8-10), and possessed of power over both mind and matter, still has only a limited free-will (Qur'an 10:99). Thus, Islam explains the nature and purpose of man, in a manner consistent with the conception of an Islamic society.

The purpose of the message revealed to the Prophet-Islam-is essentially social and moral reform. Islam, through a process of consciousness of the self, the Creator, and His creation, releases one from jähiliyah (a state of ignorance and barbarism). It prescribes a society based on the principles of justice, brotherhood, and equality. It lays out very high moral standards and expects every individual to fulfill his/her obligations to society in maintaining amān (peace and harmony) and zakat (distributive justice). In an Islamic society, individuals are responsible for their actions and are accountable to God for their conduct. The establishment of an Islamic society with strong family traditions is one of the divine duties of every Muslim. As Islam makes no distinction between spiritual and temporal or between religious and secular, all social forms, functions, and institutions should manifest the application of basic Islamic principles. ${ }^{23}$

Mannan describes an integrated individual-society-state social framework in Islam. ${ }^{24} \mathrm{He}$ maintains that this social framework is based on nine criteria: a fair balance between worship and work; human equality; mutual responsibility and cooperation in society; distributive justice; family, collective, and individual responsibility; a balanced and salutary use of God's bounty; the limited sovereignty of people in society; the principle of coexistence; and freedom of action and conscience. These criteria, he believes, will provide the motivation for those economic and social activities that will culminate in a just and egalitarian society.

The architecture of an Islamic society is an issue by itself. What is germane here is that the Islamic economic model recognizes the need to establish a functional Islamic society before its economic principles can be employed for social good. ${ }^{25}$

\section{The Economic Functions of an Islamic State}

The Islamic state is obviously the prerequisite to the establishment of an Islamic politicoeconomic order. It is distinct from other forms of polity 
in its philosophical foundations and structure, as well as in its functional features. An Islamic polity represents the institutionalization of the ummah's desire to realize the maqāsid al sharï $a h$. The Islamic state can be realized only through a conscious application of Islam's sociopolitical and economic principles both at the level of human action and of institutional practice. It assumes the submission to Islam by all members and a willingness to establish a society based on justice and equality. It assumes a degree of $t a q w \bar{a}$ (consciousness) or faith capable of negating individual desires for power and wealth, in deference to social welfare, on the part of the masses. It also assumes a high level of awareness among the people regarding the teachings of Islam accompanied by a well-nurtured moral character. Of all forms of statehood, Islam expects the most from its subjects. And why not, for was not humanity made from the best of molds (Qur'an 95:4)?

At this point, one must understand clearly that if the masses are weak in their belief in tawhid and a just society, then the task of the state becomes more difficult. It will have to enforce these principles. In an ideal Islamic state, which is nonexistent today but was a phenomenal success under the Prophet and the first four caliphs, the state merely coordinated the implementation of zakat and the self-motivated avoidance of $i$ isräf (waste) and ribā (interest). There was no need for the state to intervene or enforce its laws, for everyone believed that they were God's vicegerents and conducted themselves accordingly. At the time of Hārūn al Rashid, the society was so well-balanced that there was no one to whom it could give alms.

By now it must be clear that secularism, as defined in liberal and communist states, is absolutely irrelevant to the Islamic political covenant. Religion is inalienably associated with politics and economics, for it both defines the objectives and also prescribes the means. Thus, in Islamic thought, political economy is a valid category of science, for politics and economics cannot be dissociated from each other. To summarize, the raison d'être of the state is to establish a society in which there is social equality and economic justice with human well-being and the good life as goals, an economy based on the principles of tawhid and amänah. This is the role of the state as defined by the principles of Islamic political economy.

\section{Fundamental Principles}

This section describes those fundamental principles of Islam that are both articles of faith as well as instruments of policy. It is the simultaneous manifestation of the dual characters of these principles that constitutes Islamic political economy.

\section{Tawhìd and Brotherhood}

Tawhid signifies the belief in the encompassing unity of God and the acceptance that He alone is the Creator and Sustainer and is alone worthy 
of worship. Any violation of this is a cardinal sin known as shirk (the consecration of anything else but God):

Your God is One God: As to those who do not believe (in One God and the hereafter), their hearts refuse to know and they are arrogant. (Qur'an 16:22)

The theme of unity is fundamental in Islam and runs through the Qur'an. ${ }^{26}$ Tawhild, in a broader sense, means divinity and also incorporates the concept of the brotherhood of the ummah. Brotherhood implies a relationship of mutual care and universal welfare in which all Muslims are treated as one ummah, community, or nation, as well as the collective responsibility of ensuring the well-being (faläh) of each individual. It obligates humanity to maintain amänah (trust) among the ummah and to refrain from fasād (mischief, animosity, and corruption) (Qur'an 2:205), especially since all resources are in abundance, are for the welfare of all and not for just a few, and have to be utilized equitably for the well-being of all (Qur'an 2:29). The Islamic emphasis on the equitable distribution of wealth is so intense that some Muslims believe that the equality of wealth is essential in an Islamic society. ${ }^{27}$

So that it may not be (a benefit) going round and round among such of you as may (already) be rich. (Qur'an 59:7)

This verse states clearly that society should not allow the concentration of wealth, for such a condition contradicts the basic principles of equality and brotherhood. Many scholars believe that a concentration of resources is usually due to the exploitation of the weak, which Islam does not allow.

\section{Abolition of $\boldsymbol{R} i \bar{b} \bar{a}$}

O ye who believe! Devour not ribā. (Qur'an 3:130)

The Qur'an, in 2:275-80, instructs Muslims to end their dealing in ribā. Some scholars have translated ribā as "usury" or "interest," while others limit its definition to "excess." Very broadly, if in any financial transaction there is an excess on one side, it can be said to involve ribā. This practice is exploitative and counter to the goals of tawhid and brotherhood. Hence, Islamic society advocates its abolition. This viewpoint has led to the banning of interest in Islamic forms of banking, and the consequent problems in operations are a major area of research for Islamic scholars.

\section{Muḍārabah}

Mudärabah describes profit-sharing under economic cooperation. From the Qur'anic perspective, it is antithetical to ribā, for "God has permitted trade and forbidden ribā" (Qur'an 2:275). 
The Qur'an, in 2:267, also espouses an element of purity in economic transactions. This construct, with its moral and cooperative implications, can be the starting point of Islamic economic practices at the international level that will lead to economic cooperation and integration.

\section{Avoidance of Isrā $f$}

The Qur'anic meaning of $i s r a \bar{f}$ is "waste due to wanton consumption." It refers to excess production and consumption. ${ }^{28}$ The Qur'an, in 10:24, also implies that production must be socially controlled and that excess production should not be allowed to influence our lifestyles. Perhaps the avoidance of isräf must be associated with efficiency. Furthermore, it is stated plainly that there are resources in abundance and that they are sufficient for humanity - provided that they are used efficiently and equitably and that wastage and excess are avoided..$^{29}$ Hoarding and accumulation are not allowed, and the avoidance of $i s r a \bar{f}$ and $r i b \bar{a}$ is aimed at preventing the overexploitation of resources, which is harām (harmful).

\section{Right to Private Property}

This is a very important element in the entire structure of an economic system based on the principles of human equality and social justice. Even as the principle of amänah (trust) as applied to interpersonal affairs guards an individual's right to personal property, the fundamental principles of tawhid, zakat, and khiläfah make this right subordinate to society's right to redistribute resources. Obviously, the Shari'ah makes a policylevel distinction between resources and individual property. Ahmad alludes to the concept of private property as "priority" having rights of ownership over resources is akin to having the priority to use them. For example, if someone has a priority over some land and is not using it, then a fellow Muslim must be allowed to use it without claiming more than his/her rightful share.

The Qur'an, in 70:35, also stipulates that only that human being is the honored one "in whose wealth there is a right acknowledged for the poor and the impoverished" (Qur'an 70:24).

It is clear that when the rich share their wealth with the poor, they are not doing a favor to the poor but are merely fulfilling their obligation to God, who has endowed them with abundance. Their willingness to share shows that they acknowledge the right of the poor to an equal share in God's creation. ${ }^{31}$

\section{Zakat}

Islamic principles emphasize that resources are not only God's gift to all human beings but also His amānah (trust) (Qur'an 2:29). They should therefore be shared and distributed equally. Zakat is a form of charity that 
is an obligation of faith for every Muslim. It literally means tahārah (purification), namä (growth), barakah (blessing), and madh (appreciation) and must be paid from one's net worth if it is above a clearly defined threshold level (nisāb). Zakat is a very crucial instrument in an Islamic society ${ }^{32}$ for it functions as a form of transfer payment and represents the main means of bringing social equity and justice to the ummah. As God's resources are for everyone and have to be shared equally, the establishment of zakat is essential.

In matters of resource possession, all of us do not start equally. Those who have more have an obligation to share with the others, for it is not they but God-and God alone-who creates. And those who are poor have the right to a share, for God has given them the right to live as do the rest. No individual is more or less than another, by virtue of race, age, language, place of birth, lineage, or even knowledge, except in his/her taqwā (consciousness) and imān (faith) in God.

\section{The Three Perspectives of Political Economy}

This section identifies existing perspectives of political economy. It is neither the occasion nor the object to explain these various perspectives in detail, as they can be studied in other works. The discipline of political economy recognizes three worldviews or ideologies that constitute its theoretical edifice: liberalism, Marxism, and realism or neomercantilism. ${ }^{33}$ Different states use different worldviews to accomplish their political and economic goals. The collapse of the Soviet bloc is being treated by most policymakers as the end of Marxism as a contending worldview. Liberalism, along with neomercantilism, is on the ascendancy. The former is becoming the order of the day, while the latter is the standard strategy applied by such economic challengers as Japan, China, and South Korea.

It is apparent that the outcome of implementing these perspectives has not been good for everyone. Liberalism has led to vast inequities in wealth distribution, Marxism to authoritarianism and repression, and realism to international conflict. We still need to look for alternative perspectives to establish a just and universally beneficial world order.

\section{Conclusion and Directions for Future Research}

Given Muslims' belief in the timelessness of the Islamic paradigm and its applicability to all people in all ages, Muslim scholars have failed to do justice to it. It has to be reread and reinterpreted in order to explain change (from the Qur'anic perspective) and to extract from it models that will be in tune with the times. Ijtihad should be an ongoing process. This paper paints with a very broad brush. What needs to be undertaken is a detailed study of each element and principle of Islamic political economy in order to give them a practical form. Future research should not only elaborate upon each 
principle but also should use case studies to demonstrate how it could be applied in specific situations to produce beneficial results.

The last decade has seen the global resurgence of Islam. Two states have committed themselves to the implementation of Islam at all levels of society, Iran and Sudan, while many other Muslim states (e.g., Algeria, Tunisia, Tajikistan, Egypt, and Jordan) are experiencing a demand, in various degrees, for Islamization. It is an understanding of the political economic consequences of these demands that will determine the relative success of these endeavors. Those who are trying to come to terms with this unprecedented resurgence are also thinking in terms of the political economy of this resurgence. After all, the strikingly different attitude of the United Nations and the international community in enforcing international law and protecting human rights in Kuwait and Bosnia can only be explained through a political economy approach-oil. Thus, it is important that we study the political economy of Islam as well as that of Islamization.

\section{Endnotes}

1. Mohammed A. Muqtedar Khan, "Islam and the International Relations Discourse," paper presented at the Annual Convention of the International Studies Association, Chicago, 21-24 February 1995.

2. John Esposito, Islam and Development: Religion and Sociopolitical Change (Syracuse, NY: Syracuse University Press, 1980), ix.

3. Judith Miller, "The Challenge of Radical Islam," Foreign Affairs 72, no. 2 (Spring 1993): 43-56.

4. G. T. Crane and Able Amawi, The Theoretical Evolution of International Political Economy (New York: Oxford University Press, 1991), 3-26; Jeffery Friedan and David Lake, eds., International Political Economy (New York: St. Martin's Press, 1991), 17; Robert Gilpin, The Political Economy of International Relations (Princeton, NJ: Princeton University Press, 1987), 27.

5. Crane and Amawi, Theoretical Evolution, 3.

6. S. M. Hasanuz Zaman, Economic Functions of an Islamic State (Leicester, UK: The Islamic Foundation, 1991).

7. Ozay Mehmet, Islamic Identity and Development (New York: Routledge, Chapman and Hall, Inc., 1984); Nawab Naqvi, Ethics and Economics and Islamic Synthesis (Leicester, UK: The Islamic Foundation, 1981); M. Umer Chapra, Islam and the Economic Challenge (London, UK: International Institute of Islamic Thought, 1992); M. Alam Choudhary, Islamic Economic Cooperation (New York: St. Martin's Press, 1989); M. Abdul Mannan, Economic Development and Social Peace in Islam (London: Ta Ha Publishers, 1990).

8. Naqvi, Ethics and Economics, 1-35.

9. Seyyed V. R. Nasr, "Religious Modernism in the Arab World, India and Iran: The Perils and Prospects for a Discourse," The Muslim World 83, no. 1 (January 1993): 29; Chibli Mallat, "Muhammad Baqer As-Sadr" in Pioneers of Islamic Revival, ed. Ali Rahnema (London: Zed Books, Ltd., 1994), 251-72.

10. Khurshid Ahmad, "Economic Development in an Islamic Framework," in Studies in Islamic Economics, ed. Khurshid Ahmad (London: The Islamic Foundations, 1980), 17190.

11. M. Nejatullah Siddiqui, "Muslim Economic Thinking: A Survey of Contemporary Literature," in Studies in Islamic Economics, 191-316. 
12. Umer Chapra and Mokhtar Metwally, "Role of the Stock Exchange in an Islamic Economy," Journal of Research in Islamic Economics (1985): 75-82; Chapra, Islam and the Economic Challenge, 201-12.

13. Chapra, Islam and the Economic Challenge, 201.

14. Abdul Mannan, Economic Development, 19-22; also see M. Abdul Mannan, The Making of Islamic Economic Society (Cairo: International Association of Islamic Banks, 1984).

15. Zaman, Economic Functions, 119-36, 137-60, 167-97.

16. Chapra, Islam and the Economic Challenge, 7-9.

17. Abdul Mannan, Economic Development, 9-15, 60.

18. Chapra, Islam and the Economic Challenge, 3; also see M. A. Choudhury and Uzir Malik, The Foundations of Islamic Political Economy (New York: St. Martin's Press, 1992), $54,168$.

19. Abdul Mannan, Economic Development, 9.

20. Ibid., 39-41.

21. Maulana Muhammad Ali, The Religion of Islam (Lucknow, India: S. Chand \& Co., 1964), 102-6.

22. Chapra, Islam and the Economic Challenge, 251.

23. Abd al-Rahman Azzam, The Eternal Message of Muhammad (Cambridge, UK: The Islamic Texts Society, 1993), 35, 111-27.

24. Abdul Mannan, Economic Development, 40.

25. Ibid., 41.

26. See, for example, Qur'an 2:163, 6:19, 16:22, 23:91-92; 37:1-5, 38:65-8, 112:14.

27. Chapra, Islam and the Economic Challenge, 212.

28. See, for example, Qur'an 17:27; 5:90, 7:31.

29. Chapra, Islam and the Economic Challenge, 291.

30. 'Abd al Hamìd Ahmad, Nazarīyat al Isläm al Iqtișâdìyah (Cairo: 1960).

31. See, for example, Qur'an 4:7, 6:12, 2:267.

32. For example: "... and establish regular prayers and zakat" (Qur'an 2:277) and "so establish weight with justice and do not fall short of the balance" (Qur'an 55:7-9).

33. Gilpin, Political Economy, 25-40. 